\title{
EAMR
}

European Accounting and

Management Review

EUROPEAN ACCOUNTING AND MANAGEMENT REVIEW · VOL. 3, NO. 2, 1-16 MAY 2017

\section{Accounting ratio-based predictions: an analysis of the relationship between indicators of financial health and those of accounting manipulation}

\author{
Joan Llobet-Dalmases \\ Universitat Oberta de Catalunya \\ Dolors Plana-Erta \\ Universitat Oberta de Catalunya \\ Àngels Fitó \\ Universitat Oberta de Catalunya
}

Received May 1, 2017; accepted May 29, 2017.

\begin{abstract}
Against a backdrop of global accounting harmonization, financial information is required to be useful and trustworthy for investors and other users. This study contributes to establishing whether there is a relationship between the Z-score model for predicting financial distress and the $\mathrm{Z}$ Vladu model for predicting earnings manipulation. Both models discriminate between companies using financial statement ratios.

Extracting data from the Sistema de Análisis de Balances Ibéricos (Iberian Accounts Analysis System, or SABI) database for medium-sized and large Spanish companies for the period 2005 to 2015 , both summary indicators have been calculated and descriptive and bivariate analyses have been performed.
\end{abstract}

The results show that there is a relationship between both indicators, albeit a weak one.

\section{KEYWORDS}

Financial distress, Z-score, earnings manipulation, earnings management, earnings quality, Spanish firms. 


\section{Introduction}

According to the conceptual framework arising from the harmonising of the accounting and financial information that has taken place over the last decade, one of the main purposes for financial information is to provide useful data on whose basis investors and other users can make decisions. Given this purpose, accounting regulations should be aimed at improving the "quality of accounting information" and hence facilitating users' decision-making processes.

This process of convergence of accounting regulations has intensified the debate on the role to be played by financial information. Within this context, a number of studies have shown that the process of reforming and adapting accounting-related business legislation has brought with it an improvement in the informational quality of financial information. According to Barth et al. (2008) this improvement in the quality of financial information has arisen as a result of both to the limitations on accounting alternatives optionally available to business, and of the introduction of valuation systems more in line with business realities. Based on these arguments, the authors show that improved quality in financial information leads to improvements in earnings quality, a reduction in earnings management and, accordingly, a reduction in earnings manipulation. This concept of earnings quality is inevitably associated with underlying financial actions and the ability of the accounting system to measure said actions (Dechow et al. 2010).

Against this backdrop of the greater importance of accounting and financial information, and of the decision-making processes that arise therefrom, it is to be expected that measures and indicators based on accounting information be intrinsically more reliable and boast a greater predictive ability. Nevertheless, whilst there have been many research works showing that international accounting reforms have been giving good results, there continue to be cases of accounting fraud with devastating consequences for the reputation of accounting and financial information systems (Amat, O. 2017).

Given this scenario, this article compares two summary indicators that provide predictions as to: a) situations of financial distress, and b) situations of earnings manipulation. In both cases, financial information-based prediction techniques are used, more specifically those based on the behaviour of certain accounting ratios.

Within the framework of accounting information-based models for predicting business insolvency, Altman's (1968) model and its subsequent developments remain the 
benchmark. One of its adaptions is that by Amat et al. (2016), to fit the Spanish context, which saw a realignment of ratios and coefficients.

Few studies of earnings management or manipulation have based their empirical analyses on the analysis of accounting ratios. Given its usefulness and the methodological parallelism of its construction with Altman's index, of particular interest is the indicator developed by Vladu et al. (2017), involving a summary indicator that allows one to distinguish between those businesses that are potentially manipulative and those that are not.

The contrasting of the two indicators will allow us to test whether there is a relationship between the Z-scores for advance detection of financial problems and that for detecting earnings manipulation.

To resolve this issue, this article is divided into two parts, as highlighted below: firstly, it will highlight the contribution of literature, to subsequently move on to tackle the methodology employed, and then continue with an analysis of the results obtained, to close with the conclusions arising from our research.

\section{The contribution of literature}

Business forecasting models, as well as earnings management (or manipulation) analysis have been the object of study in numerous works of research. Both situations - that of possible business insolvency, as well as the manipulation of book earnings-have been analysed using different techniques, some based on accounting data, others on market parameters. In the case of creative accounting, few studies have reached their conclusions based on an analysis of accounting ratios (Vladu et al., 2017).

Set out below, and taking as their common nexus the intended improvements in the quality of accounts, we highlight works analysing the use of summary indicators that have, in turn, been built on the basis of accounting ratios.

\subsection{Models predicting financial distress}

The recent economic and financial crisis has rekindled debate on the management of financial risk and the reliability of models for predicting business failure. Within the framework of models predicting business insolvency based on accounting information, that of Altman (1968) and its subsequent developments remain the benchmark. 
To develop his predictive model, Altman (1968) selected, from a set of 22 financial ratios likely to predict situations of insolvency, a combination of five ratios able to differentiate between companies that are bankrupt and those that are not. By means of linear discriminant analysis (LDA), he drew up a summary indicator, also known as the Z-score, made up of five accounting ratios, each weighted by a coefficient. The five ratios used each belonged to one of the following categories: liquidity, earnings, leveraging, solvency and asset turnover.

$$
Z=1.2 X_{1}+1.4 X_{2}+3.3 X_{3}+0.6 X_{4}+0.999 X_{5}
$$

Where, $X_{1}$ is working capital / total assets, $X_{2}$ retained earnings / total assets, $X_{3}$ operating profit / total assets, $X_{4}$ market value of equity / total liabilities, and $X_{5}$ total sales / total assets.

After obtaining this summary indicator, the lower the Z-score, the higher the probability of bankruptcy. By testing this model, Altman established some ranges that allowed for the classification of businesses by their financial health.

This model, originally developed on the basis of accounting data for 66 listed US manufacturing firms, was later adapted for non-listed manufacturers (Altman, 1983). As part of the re-estimation process, the $\mathrm{X}_{4}$ value was replaced by $\mathrm{X}_{4}{ }^{\prime}$, defined as the book value of net equity/total liabilities, thus eliminating any reference to market value.

In turn, and in the same work (Altman, 1983), the author adapted the model for nonmanufacturing companies. This time, the model was named the Z'"-score and defined as follows:

$$
Z^{\prime \prime}=6.56 X_{1}+3.26 X_{2}+6.72 X_{3}+1.05 X_{4}
$$

With, in this case, $X_{1}$ being working capital / total assets, $X_{2}$ retained earnings / total assets, $X_{3}$ operating profit / total assets, and $X_{4}$ net book value / total liabilities. The intervals were defined as follows: if Z' ' is below 1.1, the company is at risk of bankruptcy, if it is greater than 2.6, the company is in good financial health, but if the value is between the two, it is difficult to forecast future developments.

Following Altman's examples, and given the limitations inherent in both the sample used and the methodology applied, many authors have analysed the goodness of the model in contexts other than the original one, and many have also come up with new solutions to 
predict business bankruptcy (Moyer 1977; Zmijewski 1984; Mensah 1984; Holmen 1988; Begley et al. 1996; Grice and Ingram 2001; Balcaen and Ooghe 2006).

Some of these authors have attempted to overcome the limitations inherent in the timebased framework of Altman's study (Begley et al. 1996; Mensah 1984). The results indicate that the predictive capacity of the model is unstable over time, and is thus affected by the financial periods analysed. In turn, Grice and Ingram (2001) contribute empirical evidence that, whilst these models are valid, their predictive capacity is worse when applied to more recent periods.

Another of the model's limitations that subsequent works have attempted to overcome is the size of the sample used by Altman and its lack of proportionality with the real state of bankrupt companies, compared with other companies with no financial risk (Zmijewski 1984). In turn, researchers such as Platt and Platt (1991) have proved that better results are obtained when the coefficients are adjusted to take account of the specific sector analysed.

Another aspect that has been questioned is whether the model should be used as a timebased predictor of business bankruptcy or rather as an indicator of financial distress, irrespective of the insolvency proceedings-related status that may arise therefrom (Grice and Ingram 2001; Tinoco and Wilson 2013; Theodossiou 1993).

Lastly, and given its geographical limitations, worthy of highlight are those studies that have analysed the applicability of the model to specific, non-American geographical contexts (Xu and Zhang 2009; Almamy et al. 2016; Bod'a and Úradníček 2016; Amat et al. 2016). Generally speaking, we can conclude that the different research carried out highlights how readjusting the coefficients, and on occasion the variables employed, on the basis of the specific situation of the geographic area analysed, ensures a better predictive capacity for the model.

In this regard, and given its importance to the work set forth below, we would note the work by Amat et al. (2016) developing a version of Altman's model that is better able to detect situations of insolvency in the context of Spain. In this case, and on the basis of a set of 40 ratios that have previously been used in the literature analysed to detect business insolvencies, linear discriminant analysis was applied to detect the combination of ratios that best discriminates companies in a situation of financial insolvency. To do this, an analysis was performed of 2,000 companies that had received short-term credits from a particular bank in 2008. Of the 2,000 credits granted, 144 showed repayment problems during the period from their granting to the end of 2010 . 
Analysis of the results obtained allowed the authors to develop a $Z^{*}$-score, different to that of Altman, which finds form in the following expression:

$$
Z^{*}=-3.9+1.28 X_{1}+6.1 X_{2}+6.5 X_{3}+4.8 X_{4}
$$

Where, $X_{1}$ is current assets / current liabilities, $X_{2}$ net equity / total assets, $X_{3}$ net earnings / total assets and $X_{4}$ net earnings / net equity. The ranges defined in this model are: if $Z^{*}$ is less than 0 , it can be established that the company may be in financial distress, and if it is above 0 , it can be regarded as enjoying good financial health.

\subsection{Models predicting accounting manipulation}

If the economic and financial crisis has placed the emphasis on financial risk and the reliability of models predicting business failure, the financial scandals occurring in recent years have added an ethical dimension to the debate on the usefulness of financial information (Ronen and Yari 2010).

Beyond the strict utility of financial information, oft-vaunted by its regulators, it has become necessary to establish a range of measures for checking what have been dubbed “opportunist" motivations (Chih, H. et al. 2008) in financial reporting. Together with measures such as legislation and penalty systems, there is a need for models that can predict earnings manipulation or fraud (Vladu et al. 2017), as, when we discover manipulation of a company's financial situation, it is not only a violation of the laws protecting investors, but also of socially accepted practices (Ball 2009).

The most widespread methods for detecting possible situations of earnings manipulation are based on variances with figures reflecting past results. On the basis that said results should be linear in their behaviour, any unexplained changes or spread would be associated with manipulated or low-quality results (Bath et al. 2008). These techniques have many limitations that negate their robustness (Dechow et al. 1995).

Instead of these techniques, Vladu et al. (2017) propose a model based on a combination of accounting ratios that is capable, on this occasion, of discriminating between companies massaging or manipulating their earnings and those that do not. By means of an LDA process very similar to that used by Altman to create his indicator, the authors have developed a summary indicator that they have named the Z Vladu-score, made up 
of four accounting ratios, each weighted by a coefficient. These four ratios refer to trends in sales, inventory, depreciation and borrowings.

$$
\text { Z Vladu }=-4.5+0.03 R_{1}+0.15 R_{2}-0.17 R_{3}+4.23 R_{4}
$$

Where, $R_{1}$ is the rate of variance of trade debtors with sales, $R_{2}$ that of stock (inventories) compared with cost of sales, $\mathrm{R}_{3}$ that of depreciation compared with property, plant and equipment, and $\mathrm{R}_{4}$ that of borrowings compared with assets.

Having obtained this score, the greater its value, the greater the probability that the company in question is manipulating its figures, with figures over 0.2 indicating a high probability of manipulation and those below -0.24 pointing to a low probability of earnings manipulation.

As the authors themselves note (Vladu et al. 2017), referring to an article by Leuz et al. (2003), the likelihood of manipulation is greater in certain territories with less punitive legislation, more concentrated shareholder structures and/or less-developed capital markets. In fact, in their article, the authors place Spain within the cluster of countries with the greatest susceptibility to earnings manipulation, in contrast to two other clusters. These results pointing to Spain as a country possessing the determinants for accumulating more practices involving earnings manipulation are confirmed in other works (Azofra et al. 2003; La Porta et al. 1998; Coppens \& Peek 2005).

It should be noted that, in the majority of articles referred to, earnings manipulation practices have the aim of increasing earnings figure for profit to, amongst other things, improve earnings estimates (Alissa et al. 2013), increase the value of shares (Baker et al. 2009), obtain a lower cost of capital (Francis et al. 2004), improve compensation plans (Holthausen et al. 1995), obtain better debt agreements (DeFond \& Jiambalvo 1994) or to avoid showing losses or decreases in income (Coppens \& Peek 2005).

Despite the fact that there is a great amount of literature analysing, on the one hand, the reliability of models predicting business insolvency and, on the other, the indicators, determinants and consequences of earnings manipulation, we are unaware of any work contrasting both situations on the basis of analysis of the summary indicators measuring them. In this regard, this article helps establish whether there is a relationship between the Z-scores for early detection of financial distress and the Z Vladu-score for detecting 
earnings manipulation. Both are LDA-based indicators and permit the classification of companies on the basis of a weighted set of different accounting ratios.

\section{Methodologies}

Based on data obtained from the SABI database for medium-sized and large Spanish companies (in terms of number of employees) in May 2017 and for the period from 2005 to 2015 , descriptive and bivariate analyses were performed to achieve the proposed goal. This period was chosen because it embraces the pre-crisis (2005 to 2007), crisis (2008 to 2013) and post-crisis (2014 and 2015) periods, according to the terms established by Spain's Instituto Nacional de Estadística (National Statistics Institute, or INE) on the basis of trends in the country's gross domestic product (GDP).

With these parameters, data on 12,614 companies was extracted from SABI. Given the requirements of the calculation of the two Z-score models, the number was reduced to leave only those companies with sufficient valid data to be able to carry out the calculations. So, to calculate Altman's Z"-score, the sample used comprised 7,708 observations $(61.11 \%$ of the total) and, to calculate Amat et al.'s Z*-score, the sample stood at $6,220(49.31 \%)$.

To compare these scores with the Z Vladu-score for accounting manipulation, we had to resize the sample, to be able to obtain the necessary calculations. So, to be able to compare Altman's Z-score with that proposed by Vladu, the sample was reduced to 4,099 observations (32.50\% of the total). In turn, to be able to compare the indicator proposed by Amat et al. with that of Vladu et al., the valid observations were reduced to 3,288 $(26.07 \%$ of the total).

Additionally, the sample was segmented as follows:

- By sector: in accordance with Spain's official classification of economic activities (CNAE) for 2009, companies were broken down by sector: agriculture (subgroups 01 to 03 ), industry (subgroups 05 to 32 and 35), construction (subgroups 41 to 43 ) and services (subgroups 33, 36 to 39 and 45 to 99) in line with Garcia-Gallego \& MuresQuintana (2013).

- By size: based on the number of workers hired in 2016, we have medium-sized companies (between 51 and 250) and large companies (more than 250).

The analysis was performed by means of traditional statistical techniques. Specifically, descriptive analysis was carried out and Spearman's Rho was used to assess whether there 
is a relationship between Altman's and Amat el al.'s Z-scores for detecting possible financial problems, and Vladu el al.'s indicator for detecting accounting manipulations.

\section{Research findings}

\subsection{Characterization of the financial health of companies according to the quality of their accounting information}

Descriptive analysis of the financial health of companies was performed using Altman's Z' and Amat's Z* models for predicting financial distress. To do this, for both models and for every year, the sample was segmented between companies enjoying good financial health and those indicating financial problems. Additionally, the quality of the information provided by the two types of organisations was identified by using the $\mathrm{Z}$ Vladu model for predicting earnings manipulation.

The results set forth in Table 1 indicate that, according to Altman's Z' -score, 1\% of companies (Column 6) have a high probability of bankruptcy, whilst 99\% (Column 12) are in good financial shape.

Furthermore, when Altman's indicator detects companies with a high probability of being bankrupt, the Z-score for earnings manipulations does not generally show a high probability (with an average of $22 \%$ ) that the organisations have manipulated their accounts (Column 2). This situation is consistent with the prior literature consulted, which indicates that, for various reasons, earnings manipulation is aimed at improving accounting results to show a more favourable financial situation.

However, when the company is classified as being in the group enjoying good financial health, the summary indicator of manipulation does not provide such a conclusive result. In Column 8 , it can be seen that, on average, for $46 \%$ of companies, with a range from $37 \%$ to $68 \%$, the probability that its financial information is manipulated is high. Accordingly, on average, 54\% of the businesses analysed (Column 10), show good financial health and a low probability that their annual accounts are manipulated.

The results are consistent across the four sectors analysed, the different sizes of companies and all the years reviewed 


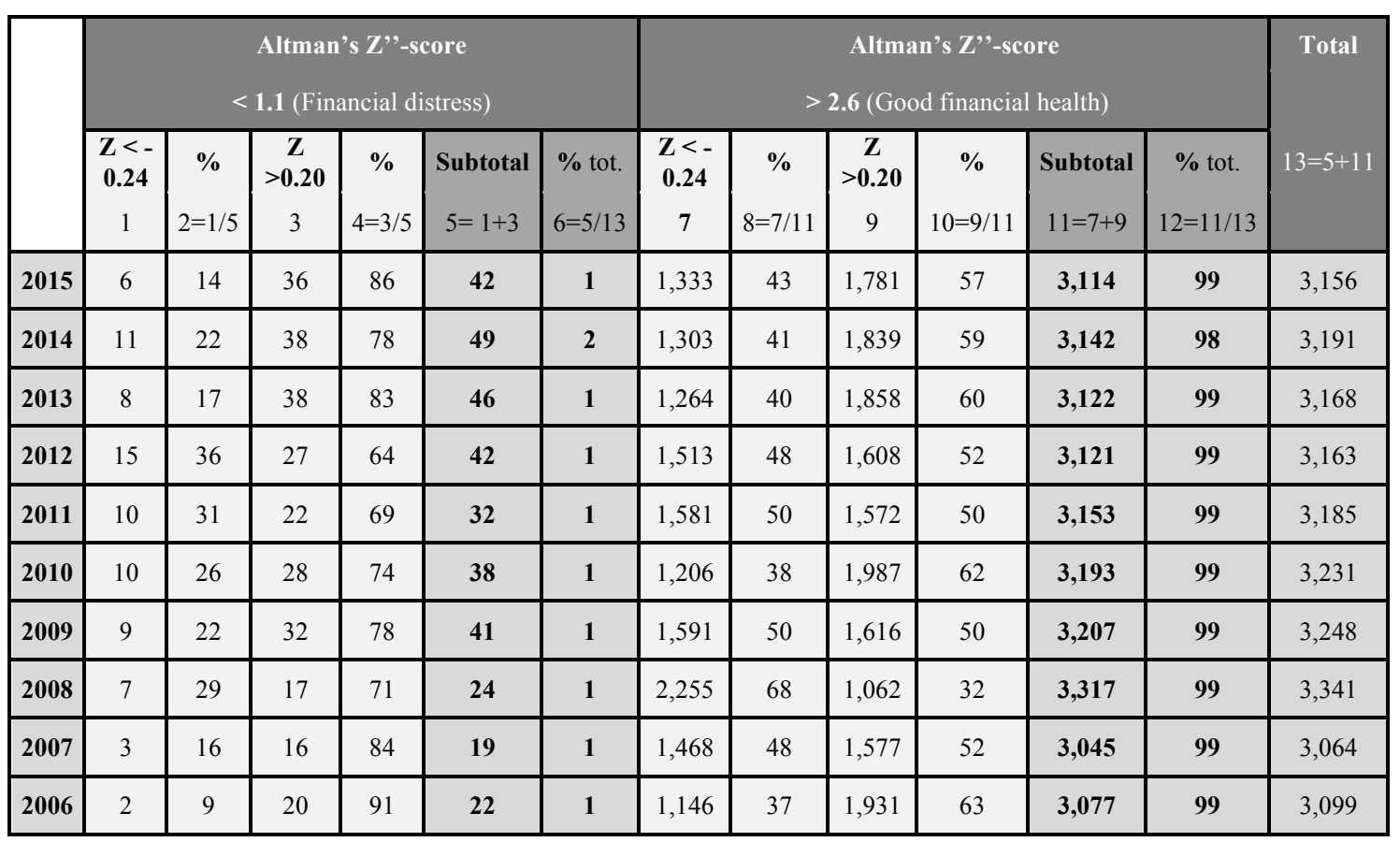

Table 1. Segmentation of the sample with the Z' and Z-scores for 2006 to 2015

Following the same procedure, but this time using Amat's Z-score, we identified that, on average, $26 \%$ of all the organisations (Column 6 of Table 2) may have financial problems whilst, on average, 74\% (Column 12) are in good financial shape.

It can also be seen that when the $Z^{*}$-score for financial distress detects companies with financial problems, the summary Z-score indicator for manipulation indicates that an average of $62 \%$ of organisations (Column 4 ) have a high probability of manipulating their annual accounts, with a range between $40 \%$ and $72 \%$. Accordingly, $38 \%$ of companies (Column 2) in which financial problems have been detected do not manipulate the earnings information they publish.

This situation, which contradicts the hypothesis that manipulations tend to inflate earnings, could be explained by situations in which the goal is to secure bankruptcy proceedings for any of the reasons already identified in literature (credit, employment and judicial situations, among others).

Also, if the $Z^{*}$-score points to the company being in good financial shape, Vladu et al.'s Z-score shows that, on average, in 50\% of companies (Column 10), with a range between $40 \%$ and $72 \%$, there is a high probability that they have filed manipulated annual accounts. Consequently, half of the businesses analysed in good financial health do not manipulate the earnings information they submit. 
The results obtained do not differ substantially if segmented by sector, business size or year studied.

\begin{tabular}{|c|c|c|c|c|c|c|c|c|c|c|c|c|c|}
\hline & \multicolumn{6}{|c|}{$\begin{array}{l}\text { Amat et al.'s } \mathrm{Z}^{*} \text {-score. } \\
<\boldsymbol{0} \text { (Financial distress) }\end{array}$} & \multicolumn{6}{|c|}{$\begin{array}{l}\text { Amat et al.'s Z*-score. } \\
>0 \text { (Good financial health) }\end{array}$} & \multirow{2}{*}{$\begin{array}{c}\text { Total } \\
13=5+11\end{array}$} \\
\hline & $\begin{array}{c}\mathbf{Z}<- \\
0.24 \\
1\end{array}$ & $\begin{array}{c}\% \\
2=1 / 5\end{array}$ & $\begin{array}{c}\mathrm{Z} \\
>\mathbf{0 . 2 0} \\
3\end{array}$ & $\begin{array}{c}\% \\
4=3 / 5\end{array}$ & $\begin{array}{c}\text { Subtotal } \\
5=1+3\end{array}$ & $\begin{array}{l}\% \text { tot. } \\
6=5 / 13\end{array}$ & $\begin{array}{c}\mathrm{Z}<- \\
0.24 \\
7\end{array}$ & $\begin{array}{c}\% \\
8=7 / 11\end{array}$ & $\begin{array}{c}\mathbf{Z} \\
>\mathbf{0 . 2 0} \\
9\end{array}$ & $\begin{array}{c}\% \\
10=9 / 11\end{array}$ & $\begin{array}{l}\text { Subtotal } \\
11=7+9\end{array}$ & $\begin{array}{c}\begin{array}{c}\% \text { tot. } \\
12=11 / 13\end{array}\end{array}$ & \\
\hline 2015 & 174 & 33 & 359 & 67 & 533 & 21 & 892 & 45 & 1,095 & 55 & 1,987 & 79 & 2,52 \\
\hline 2014 & 217 & 37 & 373 & 63 & 590 & 23 & 828 & 42 & 1,138 & 58 & 1,966 & 77 & 2,556 \\
\hline 2013 & 208 & 33 & 432 & 68 & 640 & 26 & 803 & 43 & 1,061 & 57 & 1,864 & 74 & 2,504 \\
\hline 2012 & 218 & 33 & 447 & 67 & 665 & 26 & 1,024 & 55 & 836 & 45 & 1,86 & 74 & 2,525 \\
\hline 2011 & 264 & 41 & 380 & 59 & 644 & 25 & 1,053 & 56 & 840 & 44 & 1,893 & 75 & 2,537 \\
\hline 2010 & 188 & 28 & 474 & 72 & 662 & 26 & 793 & 41 & 1,13 & 59 & 1,923 & 74 & 2,585 \\
\hline 2009 & 256 & 37 & 435 & 63 & 691 & 27 & 1,026 & 54 & 873 & 46 & 1,899 & 73 & 2,59 \\
\hline 2008 & 432 & 60 & 287 & 40 & 719 & 27 & 1,396 & 72 & 536 & 28 & 1,932 & 73 & 2,651 \\
\hline 2007 & 280 & 41 & 406 & 59 & 686 & 28 & 912 & 52 & 850 & 48 & 1,762 & 72 & 2,448 \\
\hline 2006 & 253 & 34 & 484 & 66 & 737 & 30 & 683 & 40 & 1045 & 60 & 1,728 & 70 & 2,465 \\
\hline
\end{tabular}

Table 2. Segmentation of sample with Z* and Z-scores, for 2006 to 2015

\subsection{Association between the indicators predicting financial insolvency and the indicator of earnings manipulation}

We analysed the possible association between the two Z-scores, Altman's Z' and Amat et al.'s Z*, and the summary Z-score for manipulation using Spearman's Rho, the nonparametric correlation coefficient.

Table 3 shows a significant relationship between the Z-score for earnings manipulation and each of the Z' and Z*-scores for a business's financial health.

Nevertheless, this does not mean that we can state that companies in good financial shape are less likely to manipulate the financial information they present.

The relationship established is weak, as the correlation coefficients are below $21.9 \%$, for both Z-scores and for all the years analysed. 


\begin{tabular}{|c|c|c|c|}
\hline & \multicolumn{2}{|c|}{ Financial health indicators } \\
\hline & & Z"-score & $Z^{*}$-score \\
\hline & & 2015 & 2015 \\
\hline \multirow{19}{*}{ 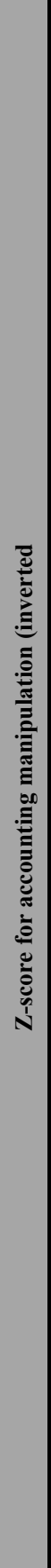 } & 2015 coefficient: Sig: & $\begin{array}{c}0.109^{* *} \\
0.000\end{array}$ & $\begin{array}{c}0.100^{* *} \\
0.000\end{array}$ \\
\hline & & 2014 & 2014 \\
\hline & 2014 coefficient: Sig: & $\begin{array}{c}0.096^{* *} \\
0.000\end{array}$ & $\begin{array}{c}0.051 * * \\
0.003\end{array}$ \\
\hline & & 2013 & 2013 \\
\hline & 2013 coefficient: $\mathrm{Sig}:$ & $\begin{array}{c}0.135^{* *} \\
0.000\end{array}$ & $\begin{array}{c}0.138^{* *} \\
0.000\end{array}$ \\
\hline & & 2012 & 2012 \\
\hline & 2012 coefficient: $\mathrm{Sig}:$ & $\begin{array}{c}0.158 * * \\
0.000\end{array}$ & $\begin{array}{c}0.219^{* *} \\
0.000\end{array}$ \\
\hline & & 2011 & 2011 \\
\hline & 2011 coefficient: Sig: & $\begin{array}{c}0.167^{* *} \\
0.000\end{array}$ & $\begin{array}{c}0.159^{* *} \\
0.000\end{array}$ \\
\hline & & 2010 & 2010 \\
\hline & 2010 coefficient: Sig: & $\begin{array}{c}0.060 * * \\
0.000\end{array}$ & $\begin{array}{c}0.109 * * \\
0.000\end{array}$ \\
\hline & & 2009 & 2009 \\
\hline & 2009 coefficient: Sig: & $\begin{array}{c}0.154 * * \\
0.000\end{array}$ & $\begin{array}{c}0.189 * * \\
0.000\end{array}$ \\
\hline & & 2008 & 2008 \\
\hline & $2008 \quad$ coefficient & $\begin{array}{c}0.140 * * \\
0.000\end{array}$ & $\begin{array}{c}0.186^{* *} \\
0.000\end{array}$ \\
\hline & & 2007 & 2007 \\
\hline & 2007 coefficient: Sig: & $\begin{array}{c}0.113^{* *} \\
0.000\end{array}$ & $\begin{array}{c}0.091^{* *} \\
0.000\end{array}$ \\
\hline & & 2006 & 2006 \\
\hline & 2006 coefficient: $\mathrm{Sig}:$ & $\begin{array}{c}0.103 * * \\
0.000\end{array}$ & $\begin{array}{c}0.071^{* *} \\
0.000\end{array}$ \\
\hline
\end{tabular}

Table 3. Spearman's Rho between the Z-score and the two scores for financial health for 2006 to 2015

** significant correlation at a level of 0.01 (bilateral)

The association's strength does not improve after segmentation by sector or company size. 


\section{Conclusions}

Against a backdrop of worldwide accounting harmonisation, in which financial information is required to be useful and trustworthy for investors and other users, this article helps establish whether there is a relationship between the Z-score indicators for the advance detection of financial problems and Vladu's Z-score for detecting earnings manipulation.

Based on data obtained from the SABI database for medium-sized and large Spanish companies (in terms of number of employees) in May 2017 and for the period from 2005 to 2015 , descriptive and bivariate analyses were performed to achieve the proposed goal. Our findings allow us to state that there is a relationship between the two indicators, albeit a weak one.

The study indicates that, in companies enjoying good financial health, according to their Z-scores (both Altman's and Amat et al.'s), more than 50\% have a high possibility of having used earnings manipulation to obtain good Z-scores. These findings are consistent with the prior literature consulted, which indicates that, for various reasons, earnings manipulation is aimed at improving accounting results to show a more favourable financial situation

Additionally, when Altman's Z-score detects financial problems, no earnings manipulation is observed. However, with Amat et al.'s Z*-score, $26 \%$ of cases saw the use of earnings manipulation. These findings, which distance themselves from the hypothesis that manipulations tend to inflate earnings, could be explained by situations in which the goals is to secure bankruptcy proceedings for any of the reasons already identified in literature (credit, employment and judicial situations, among others).

It would be interesting to improve this analysis by overcoming the limitations of our present work, such as its geographical scope (only Spain), size (by broadening the sample to include small enterprises), or having a broader database with the entirety of the data available for each of the items. 


\section{REFERENCES}

Alissa, W., Bonsall, S. B., Koharki, K., \& Penn, M. W. (2013). Firms' use of accounting discretion to influence their credit ratings. Journal of Accounting and Economics, 55(2), 129-147.

Almamy, J., Aston, J., \& Ngwa, L. N. (2016). An evaluation of Altman's Z-score using cash flow ratio to predict corporate failure amid the recent financial crisis: Evidence from the UK. Journal of Corporate Finance, 36, 278-285.

Altman, E. I. (1968). Financial ratios, discriminant analysis and the prediction of corporate bankruptcy. The journal of finance, 23(4), 589-609.

Altman, E. I. (1983). Corporate financial distress and bankruptcy: A Complete guide to predicting and avoiding distress and profiting from bankruptcy. John Wiley \& Sons.

Amat, O., Manini, R., \& Renart, M. A. (2016). Credit concession through credit scoring: Analysis and application proposal. Intangible Capital, 13(1), 51-70.

Amat, O., (2017). “Las empresas que mienten”. Profit Editorial. ISBN: 9788416904105.

Azofra, V., Castrillo, L., \& del Mar Delgado, M. (2003). Ownership concentration, debt financing and the investment opportunity set as determinants of accounting discretion: empirical evidence from Spain. Spanish Journal of Finance and Accounting/Revista Española de Financiación y Contabilidad, 32(115), 215-255.

Baker, T. A., Collins, D. L., \& Reitenga, A. L. (2009). Incentives and opportunities to manage earnings around option grants. Contemporary Accounting Research, 26(3), 649672.

Balcaen, S., \& Ooghe, H. (2006). 35 years of studies on business failure: an overview of the classic statistical methodologies and their related problems. The British Accounting Review, 38(1), 63-93.

Ball, R. (2009). Market and political/regulatory perspectives on the recent accounting scandals. Journal of Accounting Research, 47(2), 277-323.

Barth, M. E., Landsman, W. R., \& Lang, M. H. (2008). International accounting standards and accounting quality. Journal of accounting research, 46(3), 467-498.

Begley, J., Ming, J., \& Watts, S. (1996). Bankruptcy classification errors in the 1980s: An empirical analysis of Altman's and Ohlson's models. Review of accounting Studies, 1(4), 267-284.

Bod'a, M., \& Úradníček, V. (2016). The portability of altman's Z-score model to predicting corporate financial distress of Slovak companies. Technological and Economic Development of Economy, 22(4), 532-553. 
Chih, H. L., Shen, C. H., \& Kang, F. C. (2008). Corporate social responsibility, investor protection, and earnings management: Some international evidence. Journal of Business Ethics, 79(1), 179-198.

Coppens, L., \& Peek, E. (2005). An analysis of earnings management by European private firms. Journal of International Accounting, Auditing and Taxation, 14(1), 1-17.

Dechow, P. M., Sloan, R. G., \& Sweeney, A. P. (1995). Detecting earnings management. Accounting review, 193-225.

Dechow, P., Ge, W., \& Schrand, C. (2010). Understanding earnings quality: A review of the proxies, their determinants and their consequences. Journal of accounting and economics, 50(2), 344-401.

DeFond, M. L., \& Jiambalvo, J. (1994). Debt covenant violation and manipulation of accruals. Journal of accounting and economics, 17(1), 145-176.

Francis, J., LaFond, R., Olsson, P. M., \& Schipper, K. (2004). Costs of equity and earnings attributes. The accounting review, 79(4), 967-1010.

García-Gallego, A., \& Mures-Quintana, M. (2013). La muestra de empresas en los modelos de predicción de fracaso: influencia en los resultados de clasificación. Revista de métodos cuantitativos para la economía y la empresa, 15, 133-150.

Grice, J. S., \& Ingram, R. W. (2001). Tests of the generalizability of Altman's bankruptcy prediction model. Journal of Business Research, 54(1), 53-61.

Holmen, J. S. (1988). Using financial ratios to predict bankruptcy: an evaluation of classic models using recent evidence. Akron Business and Economic Review, 19(1), 52-63.

Holthausen, R. W., Larcker, D. F., \& Sloan, R. G. (1995). Annual bonus schemes and the manipulation of earnings. Journal of accounting and economics, 19(1), 29-74.

La Porta, R. L., Lopez-de-Silanes, F., Shleifer, A., \& Vishny, R. W. (1998). Law and finance. Journal of political economy, 106(6), 1113-1155.

Leuz, C., Nanda, D., \& Wysocki, P. D. (2003). Earnings management and investor protection: an international comparison. Journal of financial economics, 69(3), 505-527.

Mensah, Y. M. (1984). An examination of the stationarity of multivariate bankruptcy prediction models: A methodological study. Journal of Accounting Research, 380-395.

Moyer, R. C. (1977). Forecasting financial failure: a re-examination. Financial Management, 6(1), 11.

Platt, H. D., \& Platt, M. B. (1991). A note on the use of industry-relative ratios in bankruptcy prediction. Journal of Banking \& Finance, 15(6), 1183-1194.

Ronen, J., \& Yaari, V. (2010). Earnings Management: Emerging Insights in Theory, Practice, and Research. New York, NY: Springer Science+Business Media, LLC. 
Theodossiou, P. T. (1993). Predicting shifts in the mean of a multivariate time series process: an application in predicting business failures. Journal of the American Statistical Association, 88(422), 441-449.

Tinoco, M. H., \& Wilson, N. (2013). Financial distress and bankruptcy prediction among listed companies using accounting, market and macroeconomic variables. International Review of Financial Analysis, 30, 394-419.

Xu, M., \& Zhang, C. (2009). Bankruptcy prediction: the case of Japanese listed companies. Review of Accounting Studies, 14(4), 534-558.

Vladu, A. B., Amat, O., \& Cuzdriorean, D. D. (2016). Truthfulness in accounting: How to discriminate accounting manipulators from non-manipulators. Journal of Business Ethics, 1-16.

Zmijewski, M. E. (1984). Essays on corporate bankruptcy (Doctoral dissertation, State University of New York at Buffalo). 